\title{
Characterization of the Plasmodium vivax erythrocytic stage proteome and identification of a potent immunogenic antigen of the asexual stages
}

Wanlapa Roobsoong ${ }^{1 *}$, Sittiruk Roytrakul ${ }^{2}$, Rachada Kiatfuengfoo', Wilairat Nuchpramool', Liwang Cui ${ }^{3}$, Rachanee Udomsangpetch ${ }^{4}$

From Parasite to Prevention: Advances in the understanding of malaria

Edinburgh, UK. 20-22 October 2010

\section{Background}

With the genome of Plasmodium vivax sequenced [1], it would be important to determine proteomes of the parasite in order to assist efforts in understanding the basic biology of the parasite as well as provides the new tools for identifying novel antigens and drug targets.

\section{Materials and methods}

Lysates of $P$. vivax were separated by SDS-polycrylamide gel electrophoresis (SDS-PAGE) and proteins were identified by using matrix-assisted laser desorption/ionization-time of flight (MALDI-TOF/TOF) mass spectrometry. In addition, to identify proteins that might be
Table 1 Functional classes of all identified proteins.

\begin{tabular}{lc}
\hline Functional classes & $\%$ \\
\hline Cellular transport & 4.0 \\
Hypothetical & 48.0 \\
Metabolism & 4.0 \\
Protein fate & 5.0 \\
Protein synthesis & 4.0 \\
Protein with binding function & 10.0 \\
Unclassified & 18.0 \\
Others & 7.0 \\
\hline
\end{tabular}

\begin{tabular}{|c|c|c|}
\hline Protein name & Size (kDa) & Sequence \\
\hline Hypothetical pxotein & 24.1 & LIKDSNISFHFFYANNDPLSR \\
\hline $\begin{array}{l}\text { Hypothetical protein. } \\
\text { conserved }\end{array}$ & 110.1 & APPTOGEMLLLIVR \\
\hline Enolase, putative & 48.8 & AANPSGASTGMEALELR \\
\hline $\begin{array}{l}\text { Hypothetical peotein, } \\
\text { conserved }\end{array}$ & 41.3 & 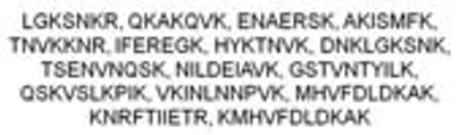 \\
\hline
\end{tabular}

Figure 1 Plasmodium vivax proteins recognized by immune serum (a), and antibody responses to PV180L protein in convalescence sera (dash line indicate ELISA cut-off value).

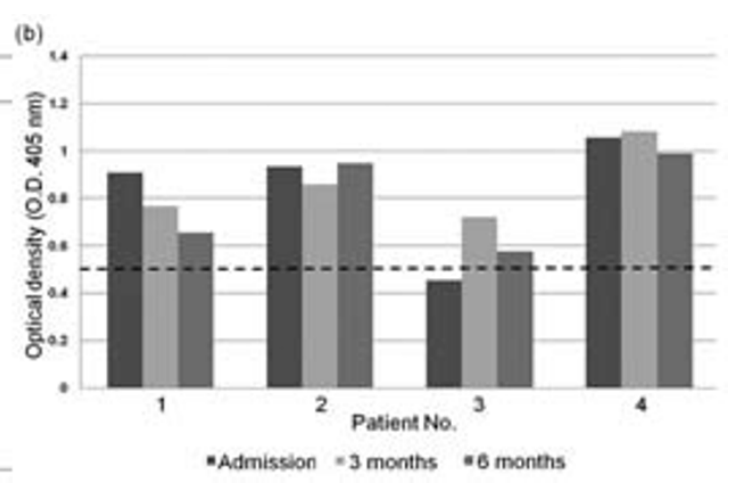

'Faculty of Medical Technology, Mahidol University, Bangkok 10700, Thailand

Full list of author information is available at the end of the article

(c) 2010 Roobsoong et al; licensee BioMed Central Ltd. This is an open access article distributed under the terms of the Creative Commons Attribution License (http://creativecommons.org/licenses/by/2.0), which permits unrestricted use, distribution, and reproduction in any medium, provided the original work is properly cited. 
recognized by host humoral immunity, we have separated them by two-dimensional gel electrophoresis. Proteins were then screened by western blot with immune serum. Spots that were recognized by the host serum were excised and identified by high-accuracy liquid chromatography-tandem mass spectrometry (LC-MS/ MS).

\section{Results}

Several hundred proteins were confidently identified. All proteins were classified into functional classes (see Table 1). Four parasite proteins were recognized by $P$. vivax-immune human sera. Interestingly, one of the four proteins (PV180L), reacted with the convalescence sera, 6 months post treatment of $P$. vivax-immune donors (see Figure 1).

\section{Conclusion}

The PV180L encodes a $24.1 \mathrm{kDa}$ hypothetical protein which expressed throughout the erythrocytic cycle of $P$. vivax and the antibodies to PV180L were long lasting. Therefore, more reports on the proteins of $P$. vivax parasite provide useful information and availability to facilitate not only basic research on this extraordinary malaria parasite, but also provide the new tools for drug and vaccine developments.

\section{Author details}

${ }^{1}$ Faculty of Medical Technology, Mahidol University, Bangkok 10700,

Thailand. ${ }^{2}$ National Center for Genetic Engineering and Biotechnology, Pathumthani 12120, Thailand. ${ }^{3}$ Department of Entomology, Penn State University, University Park, Pennsylvania 16801, USA. ${ }^{4}$ Department of Pathobiology, Faculty of Science, Mahidol University, Bangkok 10400, Thailand.

Published: 20 October 2010

\section{Reference}

1. Carlton JM, Adams JH, Silva JC, Bidwell SL, Lorenzi H, Caler E, et al: Comparative genomics of the neglected human malaria parasite Plasmo-dium vivax. Nature 2008, 455(7214):757-763.

doi:10.1186/1475-2875-9-S2-P44

Cite this article as: Roobsoong et al:: Characterization of the

Plasmodium vivax erythrocytic stage proteome and identification of a potent immunogenic antigen of the asexual stages. Malaria Journal 2010 9(Suppl 2):P44.
Submit your next manuscript to BioMed Central and take full advantage of:

- Convenient online submission

- Thorough peer review

- No space constraints or color figure charges

- Immediate publication on acceptance

- Inclusion in PubMed, CAS, Scopus and Google Scholar

- Research which is freely available for redistribution

Submit your manuscript at www.biomedcentral.com/submit 